\title{
Debating the Digital Curriculum: intersections of the public and the private in educational and cultural policy
}

\author{
MARGARET SCANLON \& DAVID BUCKINGHAM \\ Institute of Education, University of London, UK
}

\begin{abstract}
In January 2003, the British government approved the BBC's Digital Curriculum, a new $£ 150$ million initiative to provide educational software to schools and homes. The decision was widely criticised by representatives of the UK software publishing industry, and by defenders of public service broadcasting. This article traces the debates that led to the decision, and the broader issues that it raises. It suggests that the initiative can be seen as symptomatic of the interpenetration of public and private imperatives that is characteristic of New Labour policy-making; but it also suggests that, when educational and cultural policy come together, there may be unresolved tensions between them.
\end{abstract}

\section{Introduction}

Information and Communication Technology (ICT) has been widely regarded as a significant means of modernising educational practice. Harnessing the potential of ICT for learning is now seen as a key policy issue by numerous governments around the world (Furlong et al., 2000). In the UK, as part of the National Grid for Learning (NGfL) initiative, the New Labour government has spent approximately $£ 1$ bn equipping schools with computers and internet connections, training teachers and developing the NGfL portal. The provision of ICT equipment continues to proceed apace: one recent survey (Johnston, 2003) suggests that there are now 1.4 million computers in British schools, and that the government is on course to meet its targets of eight primary pupils and five secondary students per computer by 2004. While the NGfL is a central tenet of New Labour education policy, the aim of developing educational ICT infrastructures reflects international rather than purely national imperatives. Thus the NGfL initiative was one of several such policies to emerge during the 1990s, including the USA's 'Technology Literacy Challenge', Singapore’s 'ICT Masterplan', Germany's 'Schulen ans Net', Canada's 'School Net' and Malaysia's 'Smart Schools' programmes, among others (Selwyn \& Fitz, 2001). ICT now forms an integral part of educational policymaking in countries around the world, particularly in Europe, North America and South East Asia.

While the 'information superhighway' (particularly the internet) presents opportunities for governments, it also presents them with a series of dilemmas. As Kenway (1996) has pointed out, the internet pays no attention to national boundaries and it is 
not subject to government regulations. Governments are at a loss about how to deal with privacy and surveillance issues, matters of regulation, property rights, copyright, export laws, defamation and much more. Some governments are concerned with cultural imperialism and a potential loss of national identity. Thus questions have arisen with regard to what the internet is providing access to, in particular 'whose knowledge is it and what does it say to users about who they are, how they should behave and what they should value?' (Kenway, 1996, p. 225). Clearly these are matters of relevance not only to the cultural and entertainment sectors but also to education policy. Another dilemma for national governments is to do with their role in the development and dissemination of information and communication technology. In the USA, for example, politicians and technologists have disagreed over whether the role of central government is to build national information infrastructures (NIIs) themselves or merely create an economic climate that will encourage private business to take action (see Selwyn \& Fitz, 2001).

The issue of state versus industry involvement in the development of new technologies is particularly contentious in the field of education, seen in most countries as the preserve of the state. There appear to be significant differences in the ways in which governments have planned and implemented ICT policies for education, particularly in terms of how these policies relate to broader visions of national information infrastructures. Selwyn and Brown (2000) suggest that in countries such as Singapore, Malaysia, Japan and South Korea education is an integral part of broader state coordinated strategies towards NII development, whereas in the UK and the USA 'education superhighway' policies have been presented more as 'stand-alone' programmes which are driven by market forces under the 'remote control' of the state' (p. 667). In the case of the NGfL, the British government encouraged industry investment but never relinquished control over the development of the initiative. Indeed, its whole strategy with regard to ICTs in education reflects an uneasy, even sometimes quite contradictory, combination of public and private imperatives.

Of course, the apparent success of the NGfL in 'wiring up' the nation's schools does not in itself mean that effective learning is taking place. Having spent approximately one billion pounds on this initiative the government now faces the complex task of ensuring that sufficient educational software will be provided and used. The need to provide schools with access to educational software has again raised concerns about the role of public and private interests in education. In the course of this article we look at government policy-making in this area, focusing in particular on the role of the software industry and the publicly funded BBC.

In particular, we focus on a new initiative entitled The Digital Curriculum, which was finally given government approval in January 2003. The initiative will enable the leading public broadcaster, the $\mathrm{BBC}$, to spend $£ 150$ million over five years in providing digital teaching materials free to schools and homes via the internet. The announcement was greeted with 'profound disappointment' by the Digital Learning Alliance (DLA), a pressure group representing a range of commercial software companies (Cassy, 2003). Despite the government's claim that regulatory conditions would prevent the $\mathrm{BBC}$ from dominating the market, the DLA argued that the BBC was being given an unfair advantage, and that the new scheme would deprive them of substantial revenues. It would also, they suggested, deprive schools of choice.

The announcement in January 2003 was the culmination of an extended debate, which began with the publication in October 2000 of a consultation document by the BBC seeking responses to its proposals for a Digital Curriculum (BBC, 2000). The debates that ensued from this and subsequent publications were conducted in the national press, in specialist 
- In October 2000 the BBC issues a public consultation document outlining proposals to provide National Curriculum learning materials free to users over the internet and through digital TV. The 'Digital Curriculum' project is to be funded through the license fee.

- In Spring 2001 the DfEE publishes a consultation document entitled Curriculum Online, which sets out its own proposals for the development of digital learning resources via the public and private sectors. The possible role of the $\mathrm{BBC}$ in producing and/or commissioning content is discussed in detail.

- In response to the DfEE consultation document, commercial companies and their representatives voice their objections to the prospect of the $\mathrm{BBC}$ becoming both lead content provider and content commissioner within the Curriculum Online (COL) initiative. Trade associations lobby MPs, their views are aired at public meetings and in the press, and questions are asked in parliament.

- In December 2001 the government announces its plans for the Curriculum Online initiative whereby schools will receive $£ 50$ million in the form of 'e-learning credits' to buy digital materials. The Curriculum Online portal will be set up to provide a showcase of digital resources, including both free and priced materials. The industry welcomes this development but is still concerned that the BBC will go ahead with its plans for the Digital Curriculum, subject to government approval.

- In February 2002 the 'Choice for Schools' campaign is launched to campaign against the BBC's plans. This is quickly succeeded by the Digital Learning Alliance, a group which comprises publishers, broadcasters, software providers and their trade associations, and which claims to represent the majority of the education content industry in the UK.

- In May 2002 the BBC submits a revised proposal for the Digital Curriculum to the Department for Culture, Media and Sport (DCMS) for approval.

- In response to the DCMS's call for views on the BBC's proposals, the Digital Learning Alliance produces a report outlining its objections. Organisations which are members of the DLA, such as the Publishers Association, also produce their own separate responses. A number of industry-commissioned reports also appear during the summer of 2002 which claim that the Digital Curriculum will undermine the commercial market and deny users choice. Shortly after the BBC submits its revised proposals, a coalition of 18 companies is reported to be demanding a judicial review of the BBC's plans.

- In January 2003, after much delay, the Government announces its approval of the BBC's Digital Curriculum initiative. The initiative will be subject to certain controls, which will involve the $\mathrm{BBC}$ working closely with the COL Content Advisory Board, and following its recommendations. Simultaneously, the government doubles the amount (from $£ 50 \mathrm{~m}$ to $£ 100 \mathrm{~m}$ per year) given to schools in the form of 'e-learning credits' with which to purchase materials from other sources. The DLA announces that it is still considering taking the issue to the European Court or to judicial review in the UK.

educational and trade journals, and in a range of published responses and reports. In this article, we offer an analysis of these debates and the wider issues they raise, drawing on these sources and on interviews with representatives of several of the major organisations involved.

As we shall indicate, these debates raise significant questions about the relationships between the public and the private, and about the role of government as a mediator or regulator of the operations of the market, both in education and in the media. These debates have many echoes in other areas of educational and cultural policy, for example in relation to the role of private companies in education management and in the provision of learning resources, and in relation to the future of public service broadcasting and of media regulation. In this respect, the debate around the Digital Curriculum serves as a case study of broader tendencies in both areas; yet it also points to some of the complexities and contradictions that arise when the different imperatives of educational and cultural policy appear to intersect (Buckingham \& Jones, 2001). 


\title{
Supply or Demand?
}

Essentially, the debate about government involvement in online learning has centred on the question of whether it should foster a supply-led or demand-led market. The terms of this debate were clearly laid out in the government's first consultation document, Curriculum Online, published in Spring 2001. This document outlines a range of approaches to procuring digital content across the curriculum, from 'an essentially market-based approach to a more government-led one' (DfEE, 2001, p. 2). Three main options are identified, each of which (it is argued) could be combined to a greater or lesser extent with the others. In the supplyled (or 'top-down') model, the government would commission companies to produce content which would be free to users. Alternatively, it could authorise a publicly funded organisation (such as the BBC) to do so on its behalf, acting as 'lead content commissioner'. By contrast, the demand-led model would involve funding being made available directly to users so that they could select and pay for the material they want. According to its advocates, this approach encourages commercial investment in content production-and not surprisingly, this is the approach commercial companies generally prefer. As in many other areas of public policy, the government appears to favour a 'Third Way' — a mixed economy, which is claimed to offer the advantages of both the demand- and supply-led models. Yet the key question remains as to how the balance between public and private will be achieved, and which approach will be allowed to dominate in the longer term.

\section{The BBC's Proposals}

The BBC clearly saw itself from the outset as a potential content provider and 'lead content commissioner', an approach which is outlined in its proposals eventually presented to the DCMS in May 2002. The BBC justified its Digital Curriculum proposition in terms of its track record in providing learning materials and its public service remit to support education. It presented the Digital Curriculum as a logical continuation of its existing work and an extension of its 'educational mission':

\begin{abstract}
Education has since the formation of the $\mathrm{BBC}$ been one of the central pillars of its public service. Since the 1920 s, the BBC has sought to provide high quality and useful educational resources, first via radio and in print, then via television and most recently through the BBC's highly successful and widely valued education websites. The proposed service would enable the BBC to continue to deliver its educational mission into the twenty-first century, harnessing the undoubted educational benefits of Information and Communications Technologies. (BBC letter of application, 2002, p. 5)
\end{abstract}

In line with previous claims concerning the potential of e-learning, the BBC's proposals claim that the Digital Curriculum would transform education: it would 'not seek simply to transfer the structure of traditional teaching to an online environment, but instead to create an online space, in which students discover and explore concepts in innovative ways'.

Another important argument in the BBC proposals derives from the Corporation's 'brand identity'. The idea that schools do not as yet trust the internet but could be converted by the $\mathrm{BBC}$ brand is a recurring theme: 'the BBC brand would encourage users to trust the resource' (ibid, p. 11); 'harnessed together with the trusted BBC brand . . . this service should create the incentive for teachers to embrace electronic resources' (p. 4). Creating trust will in turn boost the market for everyone: 'the BBC would do its part in promoting user confidence in electronic resources as a whole, so helping to drive the wider market' (p. 11). The BBC had 
previously made similar claims in support of its Networking Club, one of the first internet service providers (ISPs) for domestic consumers in the UK. According to one BBC Online manager, the idea behind the Networking Club was to 'lead people by the hand' to the alien and intimidating internet, by way of the 'warm, fuzzy BBC brand' (quoted in Naylor et al., 2000, p. 140).

The BBC proposals were supported with three kinds of evidence-all of them somewhat partial in nature. Its public consultation was conducted over a six-week period in September and October 2000, and attracted 1,336 responses - $90 \%$ of them expressing support for the BBC's proposals. However, opponents criticised the process on the grounds of its brevity, its timing (at the beginning of the school year) and its low response rate (Digital Learning Alliance, 2002; Moss, 2000). Secondly, the BBC commissioned PricewaterhouseCoopers to conduct a review of the potential impact of the BBC's service on relevant markets. The PwC report (2002) found that - contrary to criticisms - the BBC's initiative was unlikely to be anti-competitive and could actually stimulate the overall market by making online learning more appealing to schools; and it suggested that by limiting the scope of its contribution (for example in terms of curriculum coverage), and by complementing it through e-learning credits, the $\mathrm{BBC}$ could make space for competition. However, the value of the report was somewhat vitiated by the fact that $\mathrm{PwC}$ was instructed by the $\mathrm{BBC}$ not to consult any private firms currently providing online content-as was noted in a highly critical review commissioned by the Digital Learning Alliance, and conducted by National Economic Research Associates (NERA) (2002). The third type of evidence the BBC employed in favour of its proposals was in the form of educational research, which (it claimed) showed that ICT could raise academic standards. Here again, the $\mathrm{BBC}$ was accused of selective quotation-in this instance of an evaluation of its 'BBC Bitesize' revision site conducted by the University of Durham (see Digital Learning Alliance, 2002, p. 23).

Nevertheless, the BBC was not arguing for a monopoly, but for a combination of public and private funding - and in this respect, it was clearly mindful of the extent of commercial opposition to its proposals. In this respect, its revised proposals submitted to the DCMS in May 2002 represented a careful compromise. The balance between public and private was to be struck both in terms of curriculum coverage and in terms of the proportion of externally commissioned material. While the proposed investment appeared to have increased since its initial public consultation in late 2000, the scope of the service had narrowed, becoming more focused in terms of delivery platform, age and coverage. Thus, the document proposed quotas for materials relating to core areas of the English National Curriculum and those relating to non-core areas, as well as for variations in the Scottish, Welsh and Northern Irish curricula, for minority subjects and for special educational needs. Topics would be chosen so that the Digital Curriculum service covered a maximum of $50 \%$ of the learning outcomes for any subject; and the document also proposed that $50 \%$ of the content budget would be spent on externally commissioned material. Similar quotas remained in place in the version finally approved by government in January 2003.

\section{Commercial Opposition}

Commercial software companies reacted angrily to the possibility that the $\mathrm{BBC}$ might become both a content producer and lead content commissioner. The opposition included individual companies, both large and small; and trade associations including the Publishers Association (PA) and the British Educational Suppliers Association (BESA). These organisations combined in early 2002 to form the 'Choice for Schools' campaign, which was quickly succeeded by the Digital Learning Alliance (DLA), a group which claims to represent the majority of the education content industry in the UK. Although the DLA 
includes some large media groups (Channel 4, RM, Granada and Pearson), it emphasises that many of its members are small companies, and it has tried to avoid being seen as the voice of big business.

Neil Selwyn (1999a) has noted that the discourse of technological determinism that surrounded the National Grid for Learning often hid the actors who stood to gain the most from its construction. By contrast, in the debate around the Digital Curriculum, these actors have of necessity become more visible and more vocal. In addition to working through the DLA and trade associations, some companies - particularly Research Machines (RM) and Espresso Education-have chosen to speak out openly and individually. For some, the controversy is clearly part of a much wider political debate. Thus, the Adam Smith Institute-which describes itself as being 'part of a worldwide movement towards free markets and free trade' - published a report which condemned the Digital Curriculum as 'backdoor nationalisation of the UK educational content marketplace' (McMullen, 2002, p. 5). Nevertheless, the dominant voice of opposition has come from commercial companies concerned that the $\mathrm{BBC}$ is being given an unfair competitive advantage.

While much of the opposition was mounted through responses to consultation and lobbying of various kinds, it was able to reach a much wider audience through a sympathetic hearing in some sections of the press, particularly in the Times Educational Supplement (TES) Online and the Guardian. Some of the most strident criticism of the BBC's plans came from Merlin John, editor of TES Online, who regularly castigated the BBC, at one point describing the corporation as a 'self-seeking organisation' which had 'stumped up some cash in a back-room deal' (John, 2001a, p. 18). The fact that the TES is owned by Rupert Murdoch's News International (a major commercial rival of the BBC), and that the Guardian also has commercial interests in online learning, is clearly not incidental.

Following the submission of the BBC's revised proposals to the DCMS in May 2002, the campaign against the Digital Curriculum gathered new momentum. The DLA's response to the proposals was complemented by separate responses from other member organisations and by specially commissioned research (Digital Learning Alliance, 2002; National Economic Research Associates, 2002; Publishers Association, 2002; Strategic Research Unit, 2002). Essentially, the commercial companies argued that the BBC's proposals were anticompetitive and would exclude them from the growing digital learning market. If the BBC was to provide digital content free to schools (and homes), fewer people would be willing to pay the subscription fee charged by some commercial sites. In the case of sites funded by advertising, fewer visitors would mean a fall in advertising revenues. In the longer term, it was argued, the BBC's proposed service would greatly reduce future investment because companies would be less inclined to risk entering this market.

The opponents did not wholly reject the possibility of $\mathrm{BBC}$ involvement in digital learning, but they argued that — as a public service broadcaster — it should target 'minority and specialist areas where economies of scale will preclude significant commercial investment' (Publishers Association, 2002). Even if the BBC were to commission a proportion of digital content from external providers, they argued that this would result in a much reduced role: "commercial producers would not be able to innovate if required to follow tight design briefs, and their role could be much diminished-picking up the scraps of work the BBC did not wish to carry out' (National Economic Research Associates, 2002, p. 12). They were also dismissive of some of the other concessions which the BBC appeared to be making, for example the promise to cover no more than $50 \%$ of the curriculum in any subject area. According to the Strategic Research Unit (2002) and NERA (2002) reports, covering up to $50 \%$ of the curricular learning outcomes is actually very high because in practice significantly less than $50 \%$ of the curriculum in any one school is taught using educational software. 
However, as in previous episodes in the development of the NGfL, the industry's views were often couched in altruistic terms, concerning 'choice for schools', 'quality' and the danger of teachers becoming 'the long-term losers' if the free market is not allowed to prevail (see Selwyn, 1999a). Thus, the DLA claimed in its 2002 response that 'the BBC's Digital Curriculum service will curtail choice, diversity and innovation of digital learning resources to the detriment of educators and students' (p. 3). While the Adam Smith Institute sought to frame the debate in political terms, as a matter of 'backdoor nationalisation', the industry preferred terms like 'choice' and 'diversity', and tended to draw on New Labour rhetoric, referring approvingly to public-private partnerships and the government's global vision for ICT. In this way, the potential conflict between public and private interests in education was re-framed as a matter of choice versus lack of choice.

\section{An Uneasy Compromise}

In January 2003, the government finally announced its approval of the Digital Curriculum initiative, subject to a series of regulatory conditions that - at least according to Secretary of State at the DCMS, Tessa Jowell - will prevent the BBC from unfairly dominating the market. These conditions - which are very similar to those originally proposed by the BBC in its submission to the DCMS in May 2002 — include quotas for independent commissions, and an agreement to cover no more than $50 \%$ of the curriculum (although exactly how the latter will be implemented remains to be seen). The simultaneous increase in the value of e-learning credits (eLCs) issued directly to schools will also strengthen the demand-led aspects - albeit at a level that the majority of DLA members still believe is far from adequate. (Their own market research suggests that eLCs of at least $£ 800$ million would be needed over a five year period in order to balance the BBC's investment of $£ 150$ million: see Strategic Research Unit, 2002). The government and the BBC have clearly attempted to appease the opposition; but at the time of writing (January 2003), it is far from clear that they have silenced it.

Nevertheless, cracks have begun to appear in the industry lobby, and some responses from this quarter to the January 2003 announcement were more positive. Our interviews suggest that smaller providers may not see themselves as being in competition with a huge organisation like the BBC. Some companies may be hoping to win BBC commissions, or be already collaborating on joint projects. Working with the leading brand might be seen to promise a more secure form of income than going it alone in the difficult online learning market.

\section{Economic Logic?}

The debate surrounding the Digital Curriculum has largely been driven by economic considerations. Despite the rhetoric of 'choice for schools', and the need for educational 'innovation', the commercial companies are primarily seeking to protect their profitability. For companies struggling with the advertising downturn and the after-effects of the dot.com crash, the sheer scale of the BBC's plans must have seemed like the last straw. The UK educational resources sectors are undergoing considerable change at the moment: many firms that originally supplied ICT hardware are facing increased competition and are looking for other markets to enter. RM, for example, started out as a supplier of computers to schools, but is now moving into educational content production. However, over the last year RM has reported heavy losses, which may be one of the reasons why it has been particularly vocal in its opposition to the BBC's plans (Cassy, 2002). 
Much of the enthusiasm that surrounds the World Wide Web derives from the fact that it appears to offer opportunities for more democratic forms of communication. Entry costs are much lower than for other media, and there is little regulation, allowing what Nicholas Negroponte (1995) once called a cottage industry of information providers. Yet while there is undeniably a large quantity of information available on the Web-and, to some extent, a great deal of diversity - the large multi-media companies are playing an increasingly important role. Concerns about quality control on the Web mean that companies with an established brand in other areas of the media or education have a distinct advantage. Larger companies are also in a better position to sustain initial losses - a distinct possibility in the unstable online market, where the means of generating income are still far from certain, and where significant profits have yet to be made. Multimedia conglomerates such as Pearson, Granada or Vivendi are also in an ideal position to create educational sites because they already have access to content through their ownership of publishing and software companies. In addition, they can advertise their online services through their other media. In this respect, technological convergence reinforces the tendency of changing patterns of ownership to create a more centralised industry (see Buckingham \& Scanlon, 2003). Far from undermining traditional media structures, the Web may be helping to reinforce and extend them.

The BBC's plans for a Digital Curriculum seem to exemplify this tendency. As a wellestablished multi-media company, with a strong global brand identity, the BBC is ideally placed to enter the e-learning market. It has access to existing content and expertise, and extensive promotional 'windows' in other media. In addition, BBC websites can be linked to other media products, for which customers have to pay. Although the BBC favoured a digital curriculum that would be free to schools and homes, it has always intended to generate revenues through related merchandise and overseas sales. The government's draft Eligibility Rules for Curriculum Online (DfES, 2002) state that advertising should be kept to a minimum and avoided altogether in the case of classroom material. While this clearly poses problems for the commercial sector, as it struggles to find a viable funding mechanism, the BBC already has one in place: the licence fee backed up through sales from its global commercial subsidiary, BBC Worldwide.

The fact that the $\mathrm{BBC}$ is required to commission content from outside providers may help to stimulate the market (as the Corporation itself suggests); but ultimately, over the longer term the market is bound to become more concentrated. Smaller companies will find it harder to survive, or will need to form alliances with larger companies-and these developments are likely to result in a reduction of the range and diversity of educational material available.

\section{The Role of Government}

To some extent, the role of government here is paradoxical. Broadly speaking, its policy in the field of media and broadcasting is inclined towards deregulation. While continuing to sustain the special status of the BBC, it is nevertheless keen to remove what it perceives as barriers to competition. These tendencies are clearly apparent in the Communications Act (2003), which will loosen regulatory constraints and open up terrestrial broadcasting to greater multi-national involvement. Similar tendencies are apparent in the growth of commercial involvement in education-for example, in the extension of commercial sponsorship, the Private Finance Initiative, and the contracting-out of national and local education authority services (Hatcher, 2002). Nevertheless, the guiding impulse in education policy is still towards centralising control. Despite an apparent commitment to diversity of provision (for example, in the development of specialist schools), the 
government's overriding agenda is one of standards, targets and league tables. Indeed, in offering his rationale for the extension of the Curriculum Online initiative in January 2003, Secretary of State Charles Clarke claimed 'we know from our extensive and continuing research that pupils who use ICT in the classroom get better results than those that don't' [sic] (Clarke, 2003) - an observation that many researchers would find quite contentious.

In the case of the e-learning industry, therefore, the government is bound to be torn between its desire to stimulate the commercial market-and to enable it to compete internationally - and its concern to control the curriculum. Thus far, it would seem that the latter tendency is winning out. As with the NGfL, the government seems unlikely to relinquish control over the development of the Curriculum Online initiative. As Selwyn and Fitz (2001, p. 140) suggest in the case of the NGfL, 'beneath the initiative's technological sheen, [it] does not represent the radical shift towards business-dominated education policy-making that many commentators may have originally feared'.

Thus, through the funding and regulatory framework of Curriculum Online, the government is playing a significant role in determining the resources schools have access to, and hence in turn what companies produce. In this respect, it is beginning to regulate the apparently democratic, anarchic medium of the Web. Even the mechanism by which schools can buy digital resources through Curriculum Online is tightly controlled. Teachers are not able to search the Internet and decide where they want to spend their credits: according to initial plans, eLCS can only be spent on Curriculum Online-certified products/services (DfES, 2002, p. 6). In addition, schools are being given eLCs rather than actual moneyperhaps because of fears that, if given the choice, they might redirect it elsewhere, as is alleged to have happened in the past with funding for books (Macaskill, 1999). As well as controlling funding, the government has set in place a framework for deciding what constitutes worthwhile learning resources and reliable content providers. Even providers of free sites will be affected by COL because the portal 'showcases' both free and priced content. Given the publicity which the initiative will receive (and web providers badly need publicity) providers of free educational resources are bound to want to register.

In addition to acting in this way as a funder and as a gatekeeper, the government may also use the Curriculum Online initiative as a form of surveillance. Given that the government already has so many methods of collecting information on teachers, schools and pupils, concerns on this score might seem a little superfluous. But, as with the NGfL (Selwyn, 2000), the provision of web-based resources can also act as a conduit for information gathering. According to the government's Eligibility Rules, companies providing online content - whether free or paid for - must first be registered, and their products are subject to an ongoing 'compliance review process' in which potential 'transgressions' will be monitored and investigated (DfES, 2002, p. 11). This kind of control relates partly to issues of copyright and the presence of advertising, but it also reflects concerns about 'safety', which may have broader implications in terms of freedom of information (Lawson \& Comber, 2000).

Selwyn and Brown (2000) also suggest that connecting classrooms to the Internet and providing online resources to teachers and students could be seen as 'a way of monopolising the power to decide what is to count as "really useful" information and knowledge' (p. 677). From the initial plans provided by the DfES, it is clear that what constitutes 'really useful' information is in fact confined to the National Curriculum. Products and services certified for Curriculum Online must 'be specifically targeted at and tagged according to use in the classroom with the current Curriculum KS1-4 for use within England' (DfES, 2002, p. 7); and the BBC's Digital Curriculum also focuses primarily on the National Curriculum. 
As we have seen, the commercial sector's arguments against the BBC's Digital Curriculum were partly framed in terms of 'diversity' and 'choice'. For example, it was claimed that allowing the $\mathrm{BBC}$ to become lead provider and content commissioner would be 'dangerously close to imposing a set of national text books on every school' (see Johnston, 2001, p. 4). The analogy with book publishing is certainly telling: the suppliers of educational textbooks do not currently have to be approved by the government, so it is hard to see why this should be the case with digital content. However, it is doubtful whether a 'free' market would guarantee diversity and choice, as its advocates allege. As in the field of book publishing (see Buckingham \& Scanlon, 2003), there are few commercial incentives for companies to provide diverse and innovative content, or to cater for areas outside the core National Curriculum subjects, particularly as the market becomes more competitive.

\section{Public and Private: the role of the BBC}

The contrasting arguments we have been describing here have typically been justified in terms of the New Labour rhetoric of public/private partnership (PPP). Thus, one DfES news release hailed Curriculum Online as 'the world's first partnership between the Government, leading public/private broadcasters and innovative software producers to provide materials for every curriculum subject to transform learning in schools' (DfES, 2001). Likewise, in an article about the digital curriculum, Frank Flynn, controller of BBC children's education, claimed that 'we are convinced that the answer lies in private/public partnerships' (Flynn \& Davy, 2001); while trade associations and the Digital Learning Alliance employ similar rhetoric. Despite the deep-seated conflicts of interest here, all the parties involved appear keen to use the rhetoric of the PPP in support of their position-although they clearly have very different conceptions of the role of public and private interests in education.

In this instance, the picture is particularly complicated because of the involvement of the $\mathrm{BBC}$. Historically, the $\mathrm{BBC}$ has been seen as a unique national institution, with a mission to 'educate, inform and entertain'. While it is funded from a form of compulsory taxationthe license fee-it is not a 'state broadcaster' managed by a government department, like public channels in many other countries. There have always been questions about the BBC's independence from government-not least because its governors are appointed by the government of the day. Yet ministers have often criticised what they regard as the BBC's editorial bias; and during the 1980s, Prime Minister Margaret Thatcher was clearly seeking to privatise the $\mathrm{BBC}$, which she saw as an anomaly in the context of her government's 'free market' policies (Leapman, 1986).

The Corporation has survived, although political, economic and technological changes over the last few decades have meant that its privileged position is increasingly under threat. On one level, the BBC has responded to changing times by becoming more involved in commercial activities, particularly through the work of its Worldwide subsidiary, which controls merchandising and global sales. The Corporation is in better financial shape than some of its terrestrial commercial rivals, which have been particularly affected by recent falls in advertising revenues. Yet the BBC is caught in a fundamental contradiction: it is expected to compete and to generate income, but the more commercial it becomes, the more people may question the need for a compulsory licence fee. In order to justify the continuation of the licence fee, the BBC often emphasises its traditional public service role, particularly in relation to education. As we have seen, this was a key element in its submission to the DCMS for the Digital Curriculum; and indeed, its renewed emphasis on education appears to have been one of the reasons for the increase in the licence fee in 2000, as its original Consultation Document (BBC, 2000) makes clear. The 'educational' dimensions of the BBC's brand identity also carry a significant commercial value, not least in global markets; and in 
protecting and boosting its unique position, the government could be seen to be playing the role of a 'developmental state.'

Yet for its domestic competitors, the BBC is considered to enjoy an unfair advantage, behaving increasingly like a commercial company whilst at the same time enjoying public funding. Educational broadcasters whom we interviewed argued that the BBC should not be 'duplicating other people's successes', or competing directly with commercial providers. The BBC's online strategies appear to have brought the Corporation into more direct conflict with commercial companies than ever before. Thus, in the past it has been criticised for using content from licence fee-funded television and radio programmes on its commercial web site, 'beeb.com', and for attempting to move into the free internet service provider (ISP) market with a service called 'freebeeb.net'. As Naylor et al. (2000) point out:

The advent of the Web as a major medium has certainly had a destabilizing effect on the basic compromises - regulatory, financial and managerial-on which the institution of the $\mathrm{BBC}$ is founded, transgressing the set of internal and external barriers and borders that have been so carefully constructed. Specifically, the coming of the Web had destabilized the boundary between the $\mathrm{BBC}$ and the commercial media; it has eroded the internal boundaries between different media and between the Corporation's commercial and publicly funded activities; and, finally, it has eroded the link between the licence fee and the national audience. (p. 148)

The Digital Curriculum looks set to continue this process. In addition to further blurring the boundaries between public and private, it also raises questions about access-particularly insofar as it is partly designed to be used by children at home. While the large majority of households have television, and are therefore liable to pay the licence fee, only a minority have access to the Internet.

Meanwhile, some commentators are predicting that this 'headlong rush' to digital resources will inevitably result in the decline of the BBC's schools television service. Robin Moss, former head of educational broadcasting at the Independent Television Commission, objects to what he sees as the down-grading of schools broadcasting on a number of grounds: schools TV is still popular (particularly in primary schools), ICT has not been proven to be more effective than television, and far more people have access to television than to the internet (Moss, 2000). The BBC has rejected most of these accusations, although Michael Stevenson (former BBC joint Director of Factual and Learning) has suggested that there might be a gradual reduction in TV and radio broadcasts over the longer term as schools move towards digital technology (Stevenson, 2002).

It could certainly be argued that the e-learning market needs to be 'jump-started' through public investment; and the BBC clearly feels that it is in a position to achieve this. However, the success of this strategy remains to be seen. For the reasons we have implied, BBC websites are among the market leaders for home users; but they may not be so strongly favoured by teachers. As yet, the BBC has little basis for arguing that it is the standard-bearer of quality in online learning, as it is claimed to be in broadcasting.

On the other hand, the BBC's involvement in the Digital Curriculum has been seen to represent a shift in its relationships with government. Thus, the pressure group Voice of the Listener and Viewer has suggested that the BBC may compromise its independence from government if it is required to follow the dictates of the DfES in providing educational materials. While the BBC can certainly point to its other educational services, which are not based on the National Curriculum, the remit of the Digital Curriculum appears to be much narrower. 


\section{Teacher Involvement}

One of the most significant absences from this whole debate has been the voice of teachers and other education professionals - who, in market terms, are ultimately the 'customers'. The government has emphasised that teachers were consulted throughout the formulation of the Curriculum Online policy, and that they will continue to exert an influence through their membership of the advisory panel. In addition, teachers will be able to post comments about COL websites or register their own sites on the portal-although this will be subject to eligibility rules of the kind described above. Yet while the use of a single portal may save a lot of time and effort, the stipulation that schools can only buy from the COL portal using eLCs clearly represents a top-down approach.

The BBC has also been keen to emphasise that it has involved teachers at every stage in the development of the Digital Curriculum. It points to the fact that it carried out a consultation process before developing its final proposals, although the response rate from the education sector was relatively low. Indeed, at around the same time, the BBC suspended its Educational Broadcasting Council, which is required to act as a formal mechanism for consultation with the education profession. At one point, Merlin John (2001b) of the TES tried to involve teachers in the debate by pointing out that what may appear to them to be a purely commercial issue is important because it will determine what they have access to in the future. Yet the apparent indifference or lack of engagement on the part of teachers appears to be part of a wider trend in the introduction of ICT in education (see Bigum, 1997; Kenway, 1996: Selwyn, 1999b). At the level of policy-making, ICT enjoys almost complete rhetorical hegemony; but at the level of practice, its value and effectiveness still remain to be proven. Indeed, as Larry Cuban (2001) suggests, it is precisely this marginalisation of teachers that has undermined successive attempts at educational reform, particularly those involving technology. Yet ultimately, there is no mechanism whereby teachers might be involved in initiating these plans or policies: as in educational policy more broadly, it would seem that their role is simply to 'deliver'.

\section{The Home Market}

Although both Curriculum Online and the Digital Curriculum are supposed to support learning both at school and in the home, the primary focus is on the school. As in the case of other media (see Buckingham \& Scanlon, 2003), the online education market is likely to be dominated by provision for schools, since this is larger and more predictable. As a result, the material that is available to the home market may reflect a relatively narrow conception of learning. To date, most of the main out-of-school learning sites are geared towards homework and revision for examinations (such as Bitesize, Revisewise, SOS Teacher and Homework High). To say the least, this is a long way from the utopian fantasies about the role of computers in family learning promoted by authors such as Seymour Papert (1996).

One particularly significant factor in relation to the home market is that e-learning credits will only be available to schools. For parents, the free resources on the COL portal will have a considerable advantage over the priced ones. The BBC is likely to be one of the main beneficiaries here: they will have the licence fee, the accreditation and publicity of being on the COL portal and the added advantage of being free. Some parents may decide to subscribe to priced sites if these are being used in school; but it seems more likely that teachers will use free sites in school in order that children can go on using them at home (assuming they have internet access), or to recommend free sites only. 
The political implications of this situation are paradoxical. For instance, one of the recommendations made in the Adam Smith Institute report is that individual learners (rather than schools) should be given e-credits. According to the report, this would permit the creation of e-credit courses involving more home-based learning, 'creating the opportunity for smaller, community-based learning institutions to offer a broader range of professionally-constructed courses' (McMullen, 2002, p. 20). From this perspective, the free-market argument appears to lead inexorably towards a form of computerised deschooling, which has a certain amount in common with Illich's original vision (Illich, 1973).

On the other hand, defenders of public service broadcasting have claimed that the BBC's online plans will result in license payers' money being used to pay for a service which will not be available to all homes. The BBC has justified its policy on the grounds that it pioneered television broadcasting at a time when relatively few people owned a TV set; but the counterargument, of course, is that only TV owners had to pay the license fee. By creating an educational service which is not universally available outside school, the BBC could be accused of exacerbating the digital divide which already exists between homes and, to a lesser extent, between schools. Not only will schools and homes require Internet access, but in order to fully utilise the service they will need a broadband connection. (Under present proposals, narrowband users would only be able to access $70 \%$ of the content, while broadband users or schools with a local cache would have access to $100 \%$.) There are no proposals as yet to make content available via more easily available platforms such as digital television, games consoles or mobile phones (Digital Learning Alliance, 2002, p. 8). Here again, there is an argument that the BBC, as a public service body, should be specifically concerned with ensuring universal access.

\section{Conclusion}

The debate over the Digital Curriculum has been characterised by some awkward contradictions and compromises. In this field, as in many others, the fundamental tension is between public and commercial imperatives; yet the situation is more complicated than one of straightforward opposition. In its cultural policy, particularly in the field of media, the government has largely sought to promote the free market. Yet it remains convinced of the need to preserve the role of the $\mathrm{BBC}$ as a unique public sector institution-albeit one fundamentally 'modernised' by its encounters with global economic forces. Meanwhile, in its education policy, the government is also persuaded - albeit to a lesser extent - of the merits of commercial solutions and approaches; yet it is also tied to a highly centralised, directive strategy in the belief that this alone will raise 'standards'.

As we have shown, these potentially conflicting imperatives come together in an interesting way when it comes to providing online educational content to schools. The government wants to stimulate the market in educational resources-not least because Britain can potentially become a market leader. Yet it also wants to control what can be provided to schools - and, by extension, to homes. It can see the logic of exploiting the BBC 'brand', both at home and in global markets; yet it cannot be seen to be indulging in 'backdoor nationalisation'. For these reasons, its Digital Curriculum was bound to entail a complex set of balances and compromises. Even now, the debate has yet to be finally settled-although of course the crucial test will be in how the services are actually implemented and used over the coming years.

Correspondence: David Buckingham, Centre for the Study of Children, Youth and Media, Institute of Education, University of London, 20 Bedford Way, London WC1H 0AL. Email: d.buckingham@ioe.ac.uk 


\section{Acknowledgements}

This article is based on research conducted for a project funded by the Economic and Social Research Council UK, 'Learning Online: E-Learning and the Domestic Market', March 2002-January 2003 (ref: 000223819). We would like to thank Ken Jones and Caroline Pelletier for their comments on an earlier draft.

\section{References}

BBC (2000) A Digital Curriculum: have your say, London, BBC.

BBC (2002) Digital Curriculum Service (includes letter to the Department for Culture Media and Sport (DCMS)), London, BBC.

Bigum, C. (1997) Teachers and computers: in control or being controlled? Australian Journal of Education, 41, 3, 247-261.

Buckingham, D. \& Jones, K. (2001) New Labour's cultural turn: some tensions in contemporary educational and cultural policy, Journal of Education Policy 16, 1, 1-14.

Buckingham, D. \& Scanlon, M. (2003) Education, Entertainment and Learning in the Home, Buckingham, Open University Press.

CAssy, J. (2002, 5 February) Term of trial after RM’s profits alert, The Guardian.

CASSY, J. (2003, 10 January) BBC to give away school syllabus online, The Guardian.

Clarke, C. (2003, 9 January) Foreword to Curriculum Online Supplement, Times Educational Supplement.

Cuban, L. (2001) Oversold and Underused: computers in the classroom, Cambridge, MA, Harvard University Press.

Department For Culture, Media \& Sport (DCMS) (2003) News release, 9 January.

Department for Education and Employment (DfEE) (2001) Curriculum Online: a consultation paper, London, DfEE.

Department for Education and Skills (DfES) (2001) News release, 10 December.

Department for Education and Skills (DfES) (2002) Curriculum Online Eligibility Rules, London, DfES.

Digital Learning Alliance (DLA) (2002) DLA response to BBC’s application for a Digital Curriculum service, 18 June.

FLYNN, F. \& DaVY, T. (2001, 12 June) The bigger broadcast, The Guardian.

Furlong, J., Furlong, R., Facer, K. \& Sutherland, R.(2000) The national grid for learning: a curriculum without walls? Cambridge Journal of Education, 30, 1, 91-110.

Hatcher, R. (2002) The Business of Education: how business agendas drive Labour's policies for schools, London, Socialist Education Association.

Iluich, I. (1973) Deschooling Society, Harmondsworth, Penguin.

John, M. (2001a) Lifelong learning ... until 6pm, Times Educational Supplement Online, 9 November.

John, M. (2001b) Resist the pull of big players, Times Educational Supplement Online, 11 May.

Johnston, C. (2001) Mounting opposition to Beeb’s big idea, Times Educational Supplement Online, 7 September.

Johnston, C. (2003) Training failure hinders ICT, Times Educational Supplement Online, 3 January.

KenwAY, J. (1996) The information superhighway and post-modernity: the social promise and the social price, Comparative Education, 32, 2, 217-231.

LAwson \& Comber (2000) Censorship, the Internet and schools: a new moral panic? The Curriculum Journal, 11, 2, 273-285.

Leapman, M. (1986) The Last Days of the Beeb, London, Harper Collins. 
Macaskill, H. (1999) Real money for 'real' books, The Children's Bookseller, 10 September, $16-20$.

McMuldan, T. (2002) Wired to Learn: what's holding up the school of the future? London, Adam Smith Institute.

Moss, R. (2000) Closing a window on the world: convergence and UK television services for schools, Cultural Trends, 10, 40, 3-27.

National Economic Research Associates (NERA) (2002) Market Assessment of the BBC's Digital Curriculum Proposition: a review of PriceWaterhouseCoopers' report, London, NERA.

Naylor, R., Driver, S. \& Cornford, J. (2000) The BBC goes online: public service broadcasting in the new media age. In: Gauntlett, D. (ed.) Rewiring Media Studies for the Digital Age, London, Arnold.

Negroponte, N. (1995) Being Digital, London, Hodder \& Stoughton.

PAPert, S. (1996) The Connected Family, Atlanta, GA, Longstreet.

PriceWaterhouseCoopers (PwC) (2002) Market Assessment of the BBC’s Digital Curriculum Proposition, London, PwC.

Publishers Association (2002) PA response to the BBC's proposal for a Digital Curriculum service, 22 July.

Selwyn, N. (1999a) 'Gilding the Grid': the marketing of the National Grid for Learning, British Journal of Sociology of Education, 20, 1, 59-72.

Selwyn, N. (1999b) Why the computer is not dominating schools: a failure of policy or a failure of practice? Cambridge Journal of Education, 29, 1, 77-91.

SelWyn, N. (2000) The National Grid for Learning: panacea or panopticon? British Journal of Sociology of Education, 21, 2, 243-255.

Selwyn, N. \& Brown (2000) Education, nation states and the globalization of information networks, Journal of Education Policy, 15, 6, 661-682.

Selwyn, N. \& Fitz, J. (2001) The national grid for learning: a case study of new labour education policy-making, Journal of Education Policy, 16, 2, 127-147.

Stevenson, M. (2002, 21 May) Auntie knows best, The Guardian.

Strategic ResEarch Unit (SRU) (2002) Digital Learning Resources for Schools: market effects of BBC entry, London, SRU. 